\title{
Hubungan Perilaku Hidup Bersih dan Sehat Dengan Tingkat Kebugaran Jasmani Siswa Kelas X SMAN 2 Lamongan
}

\author{
Satya Wahana ${ }^{a}$, Azizati Rochmania ${ }^{b}$ \\ ${ }^{a, b}$ Pendidikan Kepelatihan Olahraga, Fakultas Ilmu Olahraga, Surabaya, 60231, Indonesia
}

Corresponding author : azizatirochmania@ unesa.ac.id

\section{A R T I C LE INFO}

Article history:

Received 06 Juni 2018

Received in revised form 17

Oktober 2019

Accepted 10 Nopember 2018

Keywords:

Each keyword to start on a new line

\begin{abstract}
A B S T R A C T
Clean and healthy life behavior is all health behavior that is done on the awareness so that family or family members can help themselves in the health sector and play an active role in health activities in the community. Physical fitness is the ability of a person to perform daily hard activity easily without feeling tired, and still have residual or reserve energy to enjoy leisure or another purposes that can be used at any time. The purpose of this research is to understanding about relationship between clean and healthy living behavior with a level physical fitness of X class students in State Senior High School 2 Lamongan. This research is descriptive research with quantitative method. The population in this research is the students of class $X$ in State Senior High School 2 Lamongan. Sampling is non probability with total sample of 205 students from 445 students. Data analysis used in this study using statistical analysis. The results of this study can be known data of healthy and healthy living behavior of normal distribution as well as data of physical fitness which also distributed normally. The relationship between clean and healthy life behavior with physical fitness level of grade X students at State Senior High School 2 Lamongan has significant relationship and has enough correlation criteria. The result of hypothesis in this research is there is relationship of clean and healthy life behavior with level of physical fitness of class X student at State Senior High School 2 Lamongan.)Maksimal: 250 Kata) dalam bahasa Inggris.
\end{abstract}

\section{Pendahuluan}

Perilaku Hidup Bersih dan Sehat (PHBS) adalah perilaku kesehatan yang dilaksanakan atas kesadaran agar anggota keluarga bisa menolong dirinya sendiri dalam bidang kesehatan dan turut aktif dalam bidang kesehatan di masyarakat (DEPKES RI, 2007). PHBS memiliki tujuan untuk meningkatkan pengetahuan, kesadaran, dan kemauan untuk hidup bersih dan sehat agar terhindar dari berbagai macam penyakit. Anggota masyarakat yang membutuhkan penerapan PHBS salah satunya adalah anak SMA, karena masa SMA adalah masa dimana seseorang menemukan jati diri dan akan memulai beranjak dewasa.

Tubuh manusia memiliki fungsi agar dapat melakukan akttivitas sehari-hari, dengan menjaga aktivitas fisik akan meningkatan kebugaran jasmani manusia. Keburagaran jasmani dapat ditingkatkan dengan melakukan latihan fisik yang baik, benar dan rutin. Aktivitas fisik di sekolah mempunyai tujuan agar siswa memiliki tubuh yang sehat dan bugar untuk menjalani aktivitas seharihari di sekolah serta tidak mudah terserang penyakit. Peningkatan aftivitas fisik adalah salah satu kegiatan untuk pencegahan penyakit. Aktifitas fisik tidak hanya bermanfaat untuk kesehatan fisik seperti meningkatkan kesehatan jantung dan memperlancar peredaran darah, namun juga memiliki manfaat non fisik seperti meningkatkan kepercaan diri, meningkatkan kemampuan belajar dan berlatih serta membantu mengurangi stres.

Menjaga kebugaran jasmani pada waktu mudabermanfaat untuk pencapaian kesehatan dan kebugara jasmani pada usia dewasa dan lanjut. Sekolah Menengah Atas Negeri (SMAN) 2 
Lamongan merupakan salah satu sekolah negeri yang berada di kabupaten Lamongan, Provinsi Jawa Timur. Alamat sekolah ini berada di Jl.Veteran no 1 Lamongan. Dengan lama belajar 3 tahun, mulai dari kela X, kelas XI, dan kelasXII.htpp://id.m.wikipedia.org/wiki/SMA_N egeri_2_Lamongan,diakses tanggal $17 \quad \bar{M}$ ei 2017). Angka kesakitan pada tahun 2014 sebanyak 836 kasus dari 1044 siswa, tahun 2015 sebanyak 844 kasus dari 1109 siswa, dan tahun 2016 per 17 Maret sebanyak 334 kasus dari 1190 siswa. Berdasarkan keadaan tersebut di atas, maka penelitian ini perlu dilakukan untuk mengetahui hubungan perilaku hidup bersih dan sehat dengan tingkat kebugaran jasmani siswa kelas X di SMAN 2 Lamongan.

\section{Pengertian Perilaku}

Perilaku jika dijelaskan dari segi biologis, merupakan aktifitas organisme y7ang mempunyai bejntangan yang luas. Menurut Soekidjo (2007) semua aktifitas manusia yang bisa dilihat maupun tidak bisa dilihat langsung diartikan sebagai perilaku.

Menurut Bimo Walgito (2003) "Perilaku yang ada di dalam individu tidak timbul dengan sendiri, tapi akibat adanya dari rangsangan yang mengenai individu tersebut".

Menurut Soekidjo (1993) perilaku dibedakan menjadi dua macam, yaitu:

Perilaku Pasif. Perilaku pasif adalah perilaku yang tidak bisa secara langsung dapat dilihat oleh orang lain. contohnya siswa tahu dengan mengatur waktu istirahat yang cukup setelah melakukan kegiatan olahraga bisa menjadikan kondisi tubuh tetap sehat. Perilaku aktif yaitu apabila perilaku itu bisa dilihat secara langsung. Seperti seorang siswa membuang sampah pada tempatnya.

\section{Pengertian Hidup Sehat}

Menurut Kus Irianto dan Kusno Waluyo (2004) "Sehat merupakan prose tumbuh kembang manusia yang meliputi fisik, emosi, spiritual dan sosial. Sehat tidak sebatas bebas dari penyakit namun mencakup secara umum kehidupan manusia seperti aspek spiritual, psikologis, sosial, faktor lingkungan, pendidikan serta rekreasi". "Kesehatan adalah keadaan sejahtera dari badan, jiwa, dan sosial yanjg memungkinkan setiap orang hidup produktif secara sosial dan ekonomi'(Undang-Undang RI Nomor 23 tahun 1992 tentang kesehatan). "Sehat adalah dimana rasa sejahtera dari jiwa, badan, dan sosial yang bisa menjadikan setiap orang hidup produktif secara ekonomi dan sosial." (KEMENKES RI, 2011).
Perilaku Hidup Bersih dan Sehat (PHBS)

Perilaku hidup bersih dan sehat adalah perilaku kesehatan yang dilaksanakan dengan kesadaran agar anggota keluarga atau keluarga bisa merawat dirinya sendiri di bidang kesehatan dan memiliki peran yang aktif di kegiatan kesehatan di masyarakat (DEPKES RI, 2007).

Ada beberapa tatanan PHBS misalnya tatananPHBS di rumah tangga, di sekolah, di pondok pesantren, di lingkungan kerja, dan lain- lain. Dalam penulisan ini PHBS terbatas pada tatanan rumah tangga dan sekolah, dengan indikator :

\section{1). Menggunakan air bersih}

$\begin{array}{ccc}\text { Menurut } & \text { Peraturan } & \text { Menteri Kesehatan } \\ \text { Republik } & \text { Indonesia } & \text { nomor }\end{array}$ 416/MENKES/PER/IX/1990 tentang syaratsyarat dan pengawasan kualitas air disebutkan bahwa air bersih adalah air yang digunakan untuk keperluan sehari-hari yang kualitasnya memenuhi syarat kesehatan dan bisa diminum setelah dimasak. Kualitas air bersih harus memenuhi syarat kesehatan yang meliputi persyaratan mikrobiologi dengan jumlah total koliform tidak melebihi kadar maksimal yang diperbolehkan yaitu 50 per $100 \mathrm{ml}$ untuk air bukan perpipaan dan 10 per $100 \mathrm{ml}$ untuk air perpipaan, sedangkan untuk air minum jumlah koliform dan E.coli harus 0(nol) per $100 \mathrm{ml}$. Selain persyaratan mikrobiologi, air bersih harus memenuhi persyaratan fisika yang meliputi bau, zat padat terlarut, kekeruhan, rasa, suhu, warna dan juga peryaratan kimia misalnya besi, flourida, dan clorida.

2) Mencuci tangan dengan air bersih dan sabun

Air yang kotor bisa menyebabkan penyakit karena banyak mengandung kuman dan bakteri.Kuman dapat menyebar ke tangan.Ketika makan, serta bisa masuk ke dalam tubuh dan bisa menimbulkan penyakit. Dengan cuci tangan dengan sabun dan air bersih akan bermanfaat untuk membasmi kuman di tangan, mencegah penyakit, infeksi saluran pernafasan (ISPA), flu burung, dan lain-lain.

3) Menggunakan jamban sehat,

Menurut DEPKES RI (2007) "Jamban adalah suatu tempat yang memiliki fasilitas membuang kotoran yang dilengkapi dengan unit penampungan kotoran dan air untuk membersihkannya". Pembuangan tinja perlu dilakukan atau diupayakan suatu sistem yang sedemikian rupa sehingga tidak menjadi 
sumber penularan penyakit

atau

menimbulkan bau.

Menurut Soekidjo Notoatmodjo (2007) "persyaratan pokok jamban disebut sehat yaitu sebagai berikut : Tidak mengotori tanah permukaan di sekitar jamban tersebut, tidak boleh mengotori air permukaan di sekitarnya, tidak boleh mengotori air yang berada di dalam tanah di sekelilingnya, tidak terjangkau oleh serangga terutama lalat dan kecoa, sederhana desainnya, mudah digunakan, tidak menimbulkan bau, dapat diterima pemakainya, murah.

4) Memberantas jentik nyamuk; Menurut Ririh Yudhastuti (2011) "Nyamuk adalah serangga yang termasuk ordo dipetra, jenisnya banyak dan hampir terseba rmerata daratan di bumi kecuali lautan., di kutub ataupun padang pasir yang amat kering. Diperkirakan tidak kurang dari 2.500 spesies ditemukan di permukaan bumi. Meski tidak semua jenis nyamuk mendatangkan penyakit, tapi nyamuk adalah yang paling di takuti.Karena diantaranya dapat mendatangkan penyakit seperti aedes aegypti yang menyebabkan Demam Berdarah Dengue (DBD)".

Nyamuk aedes aegypti bisa dimusnakan dengan pengasapan racun serangga, Namun pengasapan saja tidak cukup, karena hanya nyamuk (dewasa) saja uang mati. Selama jentiknya tidak diberantas, maka sel telur nyamuk akan menetas dan akhirnya menjadi nyamuk (dewasa) dan bisa mengakibatkan penyakit. Maka dari itu cara yang tepat adalah memberantas jentiknya yang dikenal dengan Pemberantasan Sarang Nyamuk Demam Berdarah Dengue (PSN DBD). Menurut DEPKES RI (2007) "PSN adalah pemberantasan telur, jentik dan kepompong nyamuk yang menularkan penyakit seperti malaria, kaki gajah, demam berdarah dengue, chikungunya, di tempat perkembangbiakannya".

5) Makan buah dan sayur setiap hari

Makanan yang baik untuk siswa diharapkan memenuhi kriteria gizi seimbang yaitu susunan yang sesuai kebutuhan gizi seseorang sehingga dapat mendapakatkan kehidupan yang sehat, tumbuh, berkembang berdasarkan dari pedoman umum gizi seimbang. Pola seperti ini dimaksudkan untuk dapat melengkapi keseimbangan gizi siswa. Undang - undang nomor 36 tahun 2009 mengamanatkan untuk peningkatan mutu gizi perseorangan agar masyarakat dapat dilakukan melalui program peningkatan gizi salah satunya adalah perbaikan pola konsumsi makanan dan perilaku sadar gizi sesuai dengan kemajuan ilmu dan teknologi.

"Gizi seimbang adalah anjuran memakan makanan yang sesuai kadar kebutuhan gizi untuk hidup sehat atas dasar pedoman umum gizi seimbang "(KEMENKES RI, 2011). Buah dan sayur mengandung vitamin, dan mineral.Siswa membutuhkan vitamin, mineral, dan cairan untuk metabolisme energi, membangun jaringan tubuh, keseimbangan cairan, dan membawa oksigen untuk kerja metabolisme.

6) Melakukan aktifitas fisik setiap hari;

Menurut DEPKES RI (2007) “Aktifitas fisik merupakan kegiatan menggerakakkan tubuh yang membuat tubuh kita sehat baik kesehatan fisik, kesehatan mental, dan menjaga agartubuh tetap bugar dan sehat",

Aktifitas fisik bisa berupa kegiatan seharihari, antara lain : berkebun, mencuci pakaian, naik dan lain-lain. Ataupun bisa berupa olahraga seperti, berenang, senam, bermain sepak bola dan lain-lain. Agar mempunyai kebugaran jasmani yang baik aktifitas tersebut dilakukan secara teratur paling sedikit 30 menit dalam sehari. Adapun manfaat dari melakukan aktifitas fisik secara teratur adalah berat badan terkendali, lebih bertenaga dan bugar, terhindar dari penyakit kanker, stoke, kencing manis, jantung, dan lain- lain.

\section{7) Tidak merokok;}

"Rokok bisa dibaratkan sebagai pabrik bahan kimia. Setiap satu batang rokok yang dihisap oleh pengguna akan mengeluarkan sekitar 4.000 bahan kimia berbahaya, diantara yang berbahaya adalah Tar, Carbon Monoksida, dan Nikotin (DEPKES RI,2007). Efek negatif dari Nikotin adalah membuat tubuh ketagihan dan merusak jantung serta merusak aliran darah. Kemudian efek negatif dari Tar adalah menyebabkan kerusakan sel paru-paru dan kanker.Sedangkan CO membuat berkurangnya kemampuan darah membawa oksigen, sehingga sel-sel tubuh mati.

\section{8) Jajan sehat di kantin;}

Makanan di kantin sekolah perlu memperhatikan kebersihan dan keamanan pangan. "Keamanan pangan merupakan upaya pencegahan makanan dari cemaran kimia, biologis, dan benda asing yang bisa menggangu kesehatan manusia" (KEMENKES RI, 2011). Agar kantin sekolah selalu terjaga kesehatannya maka perlu memperhatikan sanitasi jajanannya, yaitu upaya kebersihan untuk mengendalikan faktor-faktor makanan jajanan, minuman, tempat 
dan perlengkapannya yang dapat menimbulkan gangguan kesehatan yang lainnya.

Menurut Mukono (2006) "syarat agar makanan jadi bisa dikonsumsi, antara lain :

a. Makanan tidak rusak, busuk, atau basi.

b. Memenuhi persyaratan bakteriologi yang berlaku

c. Bebas dari kuma E.Coli

d. Angak kuman E.Coli pada minuman harus nol/100ml.

9. Mengikuti kegiatan olahraga di sekolah

Menurut Kemenkes (2014), "Olahraga merupakan upaya aktifitas fisik yang dilaksanakan dengan cara berkesinambungan dengan mengikuti aturan tertentu dan tujuannya ialah untuk menambah kebugaran jasmani seseorang ". Oleh karena itu maka di sekolah dilaksanakan kegiatan olahraga bagi siswa dalam mata pelajaran PJOK. PJOK dilaksanakan seminggu sekali sesuai jadwal pelajaran yang bertujuan untuk meningkatkan kebugaran jasmani siswa.Selain itu juga dilaksanakan ekstrakurikuler yang bernuansa olahraga seperti sepak bola, pencak silat, bola voli, bola basket, tenis, bulu tangkis, dan lain-lain.Dengan harapan siswa dapat mengembangkan bakat dan potensi yang ada pada diri siswa.

\section{Menimbang berat badan dan tinggi badan}

Berat badan dikatakan normal apabila tinggi dan berat badan seimbang. Rumus menghitung berat badan ideal dengan Indeks Massa Tubuh (IMT) adalah :

IMT = Berat Badan (dalam kg) $:$ Tinggi Badan $\mathrm{x}$ Tinggi Badan (dalam meter)

Standar IMT :
$<17,0$
$17,0-18,5$
$=$ Sangat Kurus
$18,6-25,0$
$=$ Kurus
$=$ Normal
$\begin{array}{ll}25,0-27,0 & =\text { Gemuk } \\ >27,0 & =\text { Obesitas }\end{array}$

(Sumber : Permenkes Nomor 41 tahun 2014 tantang Pedoman Gizi Seimbang).

\section{Membuang sampah pada tempatnya}

"Sampah adalah sisa kegiatan sehari-hari manusia dan atau proses alam yang berbentuk padat" (UU No.18 tahun 2008). "Sampah rumah tangga adalah sampah yang berasal dari kegiatan sehari-hari dalam rumah tangga yang tidak termasuk tinja dan sampah spesifik" (PP.No.81 tahun 2012). Sampah merupakan sisa baik dari tumbuhan, manusia, maupun hewan yang tidak terpakai lagi dan dibuang ke alam dalam bentuk cair, gas, atau padat. Sampah dibagi menjadi dua, yaitu : Sampah organik dapat terurai : adalah sampah yang mudah busuk dan bisa diolah menjadi kompos. Sampah anorganik - tidak dapat terurai : adalah sampah yang tidak mudah membusuk seperti kaleng, plastik dan sebagainya. Siswa diharapkan mampu menjaga kebersihan dengan salah satunya adalah membuang sampah pada tempatnya. Agar tidak terjadi pencemaran lingkungan karena terlalu banyaknya sampah kita dapat melakukan cara 3R (Reuse, Reduce dan Recyle). Reuse berarti menggunakan kembali yang masih bisa digunakan, reduce berarti mengurangi sesuatu yang bisa jadi sampah, recycle berarti mendaur ulang kembali sampah.

\section{Tingkat Kebugaran Jasmani}

Menurut Harisenjaya (1993) "Kebugaran jasmani adalah kemampuan untuk melakukan kegiatan sehari-hari tanpa mengalami kelelahan yang berarti dan masih mempunyai sisa tenaga untuk melakukian aktifitas yang lainnya."

Menurut Sadoso yang dikutip oleh KEMENKES RI (2017) "Kebugaran jasmani adalah Kemampuan seseorang untu melakukan tugasnya tanpa menghalami kelelahan yang berarti, dan nmasih mempunyai simpanan tenaga untuk kegiatan lainnya".

Menurut Widaninggar yang dikutip oleh KEMENKES RI (2017) "Kebugaran jasmani merupakan kemampuan tubuh seseorang untuk melakukan kegiatan seharihari tanpa merasa kelelahan". Komponen kebugaran jasmani yang berhubungan dengan kesehatan terdiri dari 5 komponen dasar, antara lain :

a. Daya tahan jantung dan paru-paru merupakan kemampuan fungsional jantung dan paru-paru mensuplai oksigen untuk otot dalam waktu yang relatif lama.

b. Kekuatan otot merupakan kemampuan otot untuk menggunakan tenaga untuk mengangkat beban yang berat. Otot yang kuat membawa kemudahan untuk melakukan pekerjaan yang berat.

c. Daya tahan otot merupakan kemampuan otot untuk memaksimalkan kemampuan maksimum untuk waktu nyang relatif lama. 
d. Fleksibilitas adalah kemampuan gerak dari persendian tubuh melakukan gerak yang luas jangkauannya. ( Kemenkes RI, 2017)

Kebugaran jasmani yang stabil dapat dicapai dengan melakukan gerakan yang dapat merangsang kerja jantung dan paru-paru. Untuk mengetahui tingkat kebugaran jasmani seseorang salah satu caranya adalah melakukan tes Copper

\section{Metodologi Penelitian}

Pada penelitian ini merupakan jenis penelitian observasional dengan pendekatan studi analitik potong lintang (cross sectional). Penelitian ini menggunakan studi analitik karena penelitian ini melibatkanpengumpulan data untuk menentukan ada tidaknya hubungan antara dua variabel. Untuk mengetahui hubungan variabel independen dengan variabel dependen dimana pengukurannya dilakukan pada sesaat (serentak) maka digunakan studi analitik potong lintang.

Metode yang digunakan adalah : Kuesioner, adalah pertanyaan yang diberikan pada responden yang akan memberikan respons sesuai permintaan .(Riduwan, 2014). Dalam penelitian ini kuesioner meliputi penggunaan air bersih, cuci tangan dengan air yang bersih dan menggunakan sabun, penggunaan jamban sehat, pemberantasan jentik nyamuk, makan buah dan sayur, aktivitas fisik, tidak merokok, jajan sehat, mengikuti kegiatan olahraga, menimban berat dan tinggi bdana dan membuang sampah pada tempatnya. Tes Copper, yaitu tes untuk mengukur tingkat kebugaran jasmani dengan cara berlari selama 12 menit tanpa berhenti, jika tidak kuat boleh diselingi jalan cepat namun dilarang berhenti. Ketika terdengar aba-aba sebagai penanda waktu telah tepat 12 menit, para peserta harus berhenti di tempat itu juga, penilaian mkenggunakan tabel yang sudah tersedia (R.S. Harisenjaya, 1993).

\section{Validasi}
akan dilakukan jenis data $\begin{array}{r}\text { penelitian yang } \\ \text { dalam penelitian ini }\end{array}$ menggunakan rumus korelasi yang bisa juga dinamanakan rumus korelasi product moment. Korelasi product moment dipakai untuk mendapatkan hasil hubungan antara dua variabel. Setelah diuji validitasnya dengan bantuan program komputer SPSS 17, ternyata semua butir soal memenuhi syarat. Akan tetapi instrumen tersebut juga harus memenuhi persyaratan

reliabitias suatu instumen. Untuk itu diperlukan pula uji reabilitas instrument

\section{Reliabilitas}

Untuk melakukan uji reliabilitas instrumen dilakukan dengan menggunakan rumus alpha dan cronbach, karena skornya adalah rentangan dari beberapa nilai.

\section{Analisis Data}

Mengetahui kesimpulan akhir dari data yang diperoleh melalui penelitian, maka diperlukan metode tertentu sehingga penafsiran kesimpulan tersebut dapat dipertanggung jawabkan kebenarannya. Pada penelitian ini salah satu metode analisis yang dipakai adalah statistik. Kemudian pada penelitian ini analisa statistik yang digunakan adalah product moment dari Karl Person, pada taraf signifikan 5\%. Untuk uji hipotesis menggunakan bantuan komputer program SPSS 17.0 for Windows Evaluation Version. Cara untuk mendapatkan hasil uji hipotesis adalah sebagai berikut :

\section{Uji Normalitas}

Uji normalitas merupakan uji yang bertujuan untuk mengetahui apakah dari data tersebut merupakan berdistribusi normal atau tidak, pengujian uji normalitas ini dengan menggunakan bantuan progam bernama SPSS 17, dengan uji kolmogorov-smirnov. Kriteria yang digunakan ubtuk mengetahui normal tidaknya suatu sebaran jika $p>0,05$ sebaran dinyatakan normal, sedangkajn jika $p<0,05$ maka sebaran dinyatakan tidak normal. (Wiwit Aryanto,2013)

Mendapatkan angka korelasi itu termasuk signifikan atau tidak maka dilihat angka probabilitas atau signifikansi. Dengan ketentuan : Jika hasil signifikansi $<0,05$, hubungan kedua variabel signifikan. Jika hasil signikansi $>0,05$, hubungan kedua variabel tidak bisa disebut signifikan. Jika output SPSS pada angka korelasi diberi tanda 2 bintang $(* *)$, maka probabilitas atau signifikansi menjadi sebesar 0,01. (Jonatan Sarwono, 2009)

\section{Uji Korelasi}

Korelasi Pearson product moment digunakan untuk mengukur kekuatan hubungan dua variabel atau lebih yang berskala interval (parametrik) dimana SPSS menyebut sebagai skala (Jonathan Sarwono, 2009). Setelah data dimasukkan dan diproses maka akan muncul angka yang menunjukkan kuat atau lemahnya korelasi dengan angka kriteria seperti berikut : 
Antara $0,80-1,00$ : Sangat tinggi

Antara 0,60-0,80 : Tinggi

Antara 0,40-0,60 : Cukup

Antara 0,20-0,40 : Rendah

Antara 0,00-0, 20 : Sangat rendah

Tanda (+) artinya hubungan positif (searah), tanda (-) artinya hubungan negatif (berbalik). (Soekidjo Notoatmodjo,2007). Menentukan keputusan uji hipotesis. Hipotesis dalam penelitian ini adalah :

H0: Tidak ada hubungan antara perilaku hidup bersih dan sehat dengan tingkat kebugaran jasmani jasmani siswa kelas $X$ di SMAN 2 Lamongan.

$\mathrm{H} 1$ : Ada hubungan antara perilaku hidup bersih dan sehat dengan tingkat kebugaran jnasmani siswa kelas $\mathrm{X}$ di SMAN 2 Lamongan.

Uji hipotesis dilakukan dengan menggunakan kriteria sebagai berikut :

Jika hasil angka signifikansi hasil riset $<0,05$, $\mathrm{H} 0$ ditolak dan $\mathrm{H} 1$ diterima.

Jika hasil angka signifikansi hasil riset $>0,05$, $\mathrm{H} 0$ diterima dan $\mathrm{H} 1$ ditolak. (Jonathan Sarwono, 2009)

\section{Hasil dan pembahasan}

Penelitian ini bertujuan untuk mengetahui hubungan perilaku hidup bersih dan sehat dengan tingkat kebugaran jasmani siswa kelas X di SMAN 2 Lamongan. Hasil penelitian ini di deskripsikan secara rinci sebagai berikut :

\section{Variabel Perilaku Hidup Bersih dan Sehat}

Berdasarkan hasil kuesioner dari 205 siswa diperoleh data perilaku hidup bersih dan sehat yaitu: skor minimum $=60$, skor maksimum $=90$, median $=74$, modus $=76$, mean $=74,16$, dan standar deviasi $=5,90$. perilaku hidup bersih dan sehat siswa kelas $X$ di SMAN 2 Lamongan, sebagian besar berada dikategori sangat baik yaitu sebesar 23 siswa (11,3\%), kemudian pada kategori baik yaitu sebesar 179 siswa $(87,3 \%)$, pada kategori sedang yaitu sebesar 3 siswa $(1,4 \%)$, tidak ada termasuk berkategori kurang.

\section{Variabel tingkat kebugaran jasmani.}

Berdasarkan hasil pengukuran dari 205 siswa diperoleh data untuk tingkat kebugaran jasmani yaitu, skor minimun $=930$ meter, skor maksimum $=2550$ meter, median $=1410$, modus $=1320$, mean $=1439,49$. Berdasarkan tabel dan gambar di atas diperoleh data pengukuran tingkat kebugaran jasmani siswa kelas $\mathrm{X}$ di SMAN 2 Lamongan yang berada pada kategori sangat kurang sebanyak 150 siswa ( 44 laki laki, 106 perempuan ), pada kategori kurang sebanyak 50 siswa ( 36 laki - laki, 14 perempuan ), dikategori sedang sebanyak 3 siswa laki laki, kemudian pada kategori baik sebanyak 2 siswa laki - laki, tidak ada yang masuk dalam kategori sangat baik.

Analisis Data

Data yang dianalisa adalah data yang berkaitan dengan permasalahan yang diajukan dalam penelitian yang diperoleh dari hasil quisioner dan hasil tes tingkat kebugaran jasmani yang dilakukan oleh siswa kelas $\mathrm{X}$ di SMAN 2 Lamongan. Hasil analisis data tersebut diuraikan sebagai berikut:

Uji Normalitas

Uji normalitas menggunakan uji Kolmogorof- Smirnov melalui perhitungan komputer program SPSS 17, dengan kriteria yang digunakan adalah jika $\mathrm{p}>0,05(5 \%)$ sebaran dinyatakan nomal, dan jika $\mathrm{p}<0,05$ (5\%) sebaran dinyatakan tidak normal. Dari hasil penelitian, didapatkan data perilaku hidup bersih dan sehat yaitu $p(0,552)>0,05$, dapat diartikan data perilaku hidup bersih dan sehat berdistribusi normal. Sedangkan data tingkat kebugaran jasmani diperoleh $p(0,058)$ $>0,05$, dapat diartikan data tingkat kebugaran jasmani berdistribusi normal.

\section{Uji Hasil Signifikansi}

Menguji hubungan antara perilaku hidup bersih dan sehat dengan tingkat kebugaran jasmani siswa kelas $X$ di SMAN 2 Lamongan menggunakan uji korelasi product moment dari karl pearson dengan bantuan program komputer SPSS 17. Dari hasil penelitian didapatkan nilai dari sig $0,000<0,05$, maka dapat disimpulkan bahwa ada hubungan yang signifikan antara perilaku hidup bersih dan sehat dengan tingkat kebugaran jasmani siswa kelas $\mathrm{X}$ di SMAN 2 Lamongan.

\section{Uji Korelasi}

Pengujian korelasi ini menggunakan bantuan progam komputer SPSS 17, dengan kriteria yang digunakan adalah sebagai berikut :

$0 \quad$ : Tidak ada korelasi

$>0-0,25$ : Korelasi sangat lemah

$>0,25-0,5:$ Korelasi cukup

$>0,5-0,75:$ Korelasi kuat

$>0,75-0,99$ : Korelasi sangat kuat

1 : Korelasi sempurna

Hasil penelitian diperoleh hasil korelasi 0,319 maka hubungan perilaku hidup bersih dan sehat dengan tingkat kebugaran jasmani 
memiliki kriteria korelasi cukup. Nilai koefisien determinan diperoleh sebesar 0,102 kemudian dikalikan $100 \%$ menjadi $10,2 \%$, dengan demikian perilaku hidup bersih dan sehat memberi pengaruh 10,2 \% terhadap tingkat kebugaran jasmani.

Menentukan Keputusan Uji Hipotesis

Hipotesis dalam penelitian ini adalah :

HO : Tidak ada hubungan antara perilaku hidup bersih dan sehat dengan tingkat kebugaran jasmani siswa kelas X di SMAN 2 Lamongan.

H1 : Ada hubungan antara perilaku hidup bersih dan sehat dengan tingkat kebugaran jasmani siswa kelas X di SMAN 2 Lamongan.

Uji hipotesis menggunakan kriteria sebagai berikut : Jika probabilitas atau signifikansi < 0,05, H0 ditolak dan $\mathrm{H} 1$ diterima. Jika probabilitas atau signifikansi $>0,05$, $\mathrm{H} 0$ diterima dan $\mathrm{H} 1$ ditolak. Hasil penelitian nilai Sig $0,000<0,05$, maka dapat disimpulkan bahwa ada hubungan perilaku hidup bersih dan sehat dengan tingkat kebugaran jasmani siswa kelas $X$ di SMAN 2 Lamongan.

Penelitian yang dilakukan ini bermaksud untuk mengetahui hubungan perilaku hidup bersih dan sehat dengan tingkat kebugaran jasmani siswa kelas X di SMAN 2 Lamongan. Menerapkan perilaku hidup sehat akan menjaga kondisi fisik seseorang, perilaku hidup sehat juga di pengaruhi faktor asupan makanan, akfivitas sehari-hari, istirahat yang cukup dan kebersihan diri sendiri dan lingkungan. Gizi yang baik dan cukup akan mendukung tubuh dalam melakukan kegiatan.

Sebaliknya jika tubuh kekurangan energi maka tubuh akan merasa lemas dan tidak bisa melakukan aktivitas dengan baik. Maka dari itu pengaturan pola makanan yang baik dibutuhkan agar tubuh memiliki sumber energi yang mencukupi. Kebugaran jasmani adalah kemampuan kemampuan seseorang untuk melakukan aktifitas tanpa mengalami keleahan yang berarti dan masih mempunyai tenaga untuk melakukan aktifitas yang lainnya, untuk memperoleh kebugaran jasmani yang bagus tentu didukung oleh berbagai faktor.

Penelitian ini dikelompokkan menjadi 4 kategori dari jumlah nilai jawaban kuesioner perilaku hidup bersih dan sehat, jika kurang dari 43,76 termasuk kategori kurang, jika jumlah nilainya 43,76 sampai 62,51 termasuk kategori sedang, untuk kategori baik yaitu 62,52 sampai 81,27, jika lebih dari
81,27 termasuk kategori sangat baik. Dari penelitian ini didapatkan hasil data sebesar 23 siswa $(11,3 \%)$ berkategorikan sangat baik, kemudian pada kategori baik yaitu sebesar 179 siswa $(87,3 \%)$, pada kategori sedang yaitu sebesar 3 siswa $(1,4 \%)$, tidak ada yang masuk pada kategori kurang.

Penelitian ini menggunakan tes lari 12 menit dan untuk kategori kebugaran dikelompokkan menjadi 5 kategori, untuk pria jarak tempuh lari kurang dari 1609 meter maka termasuk kategori sangat kurang, jika jarak tempuhnya 1609 meter sampai 2011 meter termasuk kategori kurang, pada kategori sedang jarak yang di tempuh adalah 2212 meter sampai 2413 meter, jika jarak tempuh 2414 meter sampai 2815 meter maka termasuk kategori baik, untuk kategori yang terakhir yaitu sangat baik jarak yang di tempuh lebih dari 2815 meter.

Sedangkan untuk wanita, kurang dari 1529 meter termasuk kategori sangat kurang, jika jarak tempuh larinya 1529 meter sampai 1850 meter termasuk kategori kurang, untuk kategori sedang jarak tempuhnya adalah 1851 meter sampai 2252 meter, kemudian kategori baik jarak tempunnya adalah 2253 meter sampai 2654 meter, jika jarak tempuhnya lebih dari 2654 meter maka termasuk kategori sangat baik (Harisenjaya,1993). Data yang di peroleh dari penelitian ini pada kategori sangat kurang sebanyak 150 siswa ( 44 laki - laki, 106 perempuan ), pada kategori kurang sebanyak 50 siswa ( 36 laki - laki, 14 perempuan ), dikategori sedang sebanyak 3 siswa laki - laki, kemudian pada kategori baik sebanyak 2 siswa laki-laki, tidak ada yang masuk dalam kategori sangat baik.

Jika angka signifikansi hasil riset $<0,05$, $\mathrm{H} 0$ ditolak dan $\mathrm{H} 1$ diterima. Jika angka signifikansi hasil riset > 0,05, $\mathrm{H} 0$ diterima dan $\mathrm{H} 1$ ditolak. (Jonathan Sarwono, 2009). Karena angka signifikansi kurang dari 0,05 maka hipotesis dari penelitian ini didapatkan adanya hubungan perilaku hidup bersih dan sehat dengan tingkat kebugaran jasmani siswa kelas $X$ di SMAN 2 Lamongan. Perilaku hidup bersih dan sehat pasti didukung oleh kebiasaan-kebiasaan yang baik setiap harinya. Kebugaran jasmani bisa diperoleh dari perilaku hidup bersih dan sehat yang dilakukan setiap hari.

Kriteria yang digunakan untuk mendapatkan hasil normal tidaknya suatu sebaran adalah jika $\mathrm{p}>0,05(5 \%)$ sebaran dinyatakan normal, sedangkan jika $\mathrm{p}<0,05$ (5 $\%$ ) sebaran dikatakan tidak normal. (Wiwit Aryanto,2013). Hasil uji normalistas 
didapatkan data perilaku hidup bersih dan sehat yaitu $p(0,552)>0,05$, dapat diartikan data perilaku hidup bersih dan sehat berdistribusi normal. Sedangkan data tingkat kebugaran jasmani diperoleh $\mathrm{p}(0,058)>0,05$, dapat diartikan data tingkat kebugaran jasmani berdistribusi normal. Jika angka signifikansi < 0,05, hubungan kedua variabel signifikan. Jika angka signikansi >0,05, hubungan kedua variabel tidak signifikan. ( Jonatan Sarwono, 2009).

Hasil data penelitian diperole nilai koefisien Sig 0,000<0,05 ( Sig $5 \%$ ), dari hasil tersebut menunjukkan adanya hubungan yang signifikan antara hubungan perilaku hidup bersih dan sehat dengan tingkat kebugaran jasmani siswa kelas $X$ di SMAN 2 Lamongan. Hasil koefisien determinan diperoleh 0,102 yang berarti perilaku hidup bersih dan sehat memberikan pengaruh sebesar 10,2\% terhadap tingkat kebugaran jasmani dan $89,8 \%$ dipengaruhi faktor lain sebagai contoh intensitas latihan.

Seseorang yang rutin berlatih akan memiliki tingkat kebugaran yang lebih baik daripada seseorang yang tidak melakukan latihan dengan rutin. Dengan meningkatkan kebugaran fisik maka kebugaran jasmani seseorang akan ikut meningkat. Semakin tinggi intensitas latihan akan semakin baik pula kebugaran jasmani yang didapatkan. Selain itu faktor psikologis juga mempengaruhi faktor kebugaran jasmani. Ditambah dengan istirahat yang cukup maka kebugaran jasmani seseorang akan menjadi semakin baik. Dengan demikian seseorang hendaknya selalu menjaga perilaku hidup sehat agar tubuhnya memiliki tingkat kebugaran jasmani yang baik akan tidak mudah lelah dalam melakukan aktivitas sehari - hari dan terhindar dari berbagai macam penyakit yang bisa menyerang tubuh.

\section{Daftar Pustaka}

Arfianto, Yundhi. 2017. Hubungan antara gaya hidup sehat dengan kebugaran jasmani siswa kelas VIII Sekolah Menengah Pertama Negeri 1 Sleman, Yogyakarta : FIK UNY

Darmawan, Fiat Dodi. 2015. Hubungan antara perilaku hidup sehat dan tingkat kebugaran jasmani dengan prestasi belajar penjasorkes siswa kelas XI di SMA Negeri 1 Baturaden, Yogyakarta : FIK UNY
Depkes__ RI. 2014. Pedoman Gizi Olahraga Prestasi. Jakarta.

Fitriyani, Sinta 2011. Promosi Kesehatan. Jogyakarta : Graha Ilmu

Ichan, M. 1998. Pendidikan Kesehatan Olahraga. Jakarta: Dekdibud Dirjen Dekti ProyePengembangan Lembaga Pendidikan Tenaga Kependidikan. Jakarta : Depdikbud.

Hartono, Sulung Yudi. 2013. Perilaku hidup sehat dan tingkat kebugaran jasmani siswa kelas V,VI SD Negeri 1 Karangsari, Kecamatan Pengasih, Kabupaten Kulonprogo, Yogyakarta: FIK UNY

Irianto, Kus dan Waluyo, Kusno. 2004. Gizi dan Pola Hidup sehat. Bandung: Yrama Widya.

Kemdikbud_.2015. Pendidikan Jasmani, Olahraga, dan Kesehatan. Jakarta: Pusat Kurikulum dan Perbukuan, Balitbang, Kemdikbud.

Kemenkes_ RI. 2017. Modul Pelatihan Pembinaan Kebugaran Jasmani. Jakarta

Mukono. 2006. Prinsip Dasar Kesehatan Lingkungan. Surabaya : Airlangga University Press

Nuryadi,Puput_ .https://landasanstatistika.wor dpress.com/materi-kuliah/contohsoal/,diakses tanggal 21 Desember 2017

Tim Penyusun 2014. Panduan Penulisan dan Penilaian Skripsi Universitas Negeri Surabaya. Surabaya : Universitas Negeri Surabaya

Riduan, Dr, M.B.A. 2014. Pengantar Statistika Sosial, Bandung: Alfabeta 
Rinandanto, Anang. 2015. Sikap siswa terhadap perilaku hidup bersih dan sehat di SD Negeri Balangan 1 Kecamatan Minggir Kabupaten Sleman. Yogyakarta: FIK UNY

Sarwono, Jonathan. 2009. Statistik itu Mudah : Panduan Lengkap Untuk Belajar Komputasi Statistik Menggunakan SPSS 16, Yogyakarta. Andi offset

Senjaya, RS. Hari. 1993. Penuntun Tes Kesegaran Jasmani. Refika Aditama Walgito, Bimo. 2003. Psikologi Sosial. Yogyakarta: Andi offset.

Yudhastuti, Ririh. 2011. Pengendalian Vektor dan Rodent. Surabaya : Pustaka Melati 